\title{
Pembentukan Kepribadian Akhlakul Karimah Anak Di Lingkungan Keluarga Nikah Dini Di Kecamatan Lubuk Besar Kabupaten Bangka Tengah
}

\author{
Istiqamah \\ Mahasiswa Pascasarjana; \\ IAIN Syaikh Abdurrahman Siddik Bangka Belitung; \\ Bangka, Indonesia; \\ istiqomah@gmail.com; \\ Suparta \\ Dosen Pascasarjana; \\ IAIN Syaikh Abdurrahman Siddik Bangka Belitung; \\ Bangka, Indonesia; \\ istiqomah@gmail.com;
}

\begin{abstract}
This research aims to: to know, understand and expose the virtues of the formation of good behavioral personality and methods used in the formation of good behavior personality of children in early marriage family environment in Lubuk Besar Sub-District bangka tengah regency. As for finding solutions to the above problems researchers use the following methodology: in this study researchers used a qualitative approach to phenomenology is to observe social symptoms, and the role of each individual to educate children and families in each member of society. Because every education has a purpose to build a good behavior, there is a pattern of empathy and a role that contains and implements educational values or that every family has the right to educate and be responsible for educating children and their families.

The main informants in this study are the key informants in this study are Islamic Religious Education teachers and landfill teachers and the informants in this study are families and children of early marriage perpetrators, then for the supporting informants are the sub-district staff of Lubuk Besar to look for data on the general picture of Lubuk Besar Sub-District. And the data collection techniques in this study are observation techniques, interviews and documentation. Then the analysis techniques that researchers use are data reduction, data presentation and data verivcation. The result of this study is that the first, the formation of personality akhlakul kaimah in the early marriage family environment does not go the maximum, because the family as the person shaper of the child does not have enough provision in building a household so that parents who are married early have not been able to apply everything that is the responsibility as a parent in educating and raising the child. Second, as a large number of children have poor adab and morals and some children born to early married parents have physical and psychological disabilities such as being born in un-normal circumstances. Third, among parents who are married early already married two to three times due to various domestic conflicts that occur in early marriage families caused by the economy, as well as other problems.
\end{abstract}


Fourth, most parents who marry early are more entrusted to teachers whether schoolteachers or teachers where their children learn to pay in providing religious education to the Fifth child, the causative factor of early marriage in Lubuk Besar Subdistrict is mainly due to economic, educational, parental factors and free associations that are stuck with the wrong courtship style. Although in Islam there is no age limit when a person will marry, but early marriage is highly discouraged because it will be fatal in either the home life or the child of an early marriage perpetrator if not provided with sufficient knowledge in educating children and households. Sixth, the average observer is an early marriage and a housewife. Seventh, the adverse effects of early marriage in Lubuk Besar sub-district include depression (crazy), not being able to take care of children, family conflict, early divorce, economic pressures, family disharmony, risky pregnancies, the head of the family difficulty finding work due to the lack of experience before marriage. Thus it is highly discouraged for today's young people to perform underage marriages. Because it will not only affect him and his family but also on the children of early marriage abusers who will become the next generation of the nation.

Penelitian ini bertujuan untuk: untuk mengetahui, memahami dan memaparkan Keutamaan pembentukan kepribadian akhlakul karimah dan Metode yang digunakan dalam pembentukan kepribadian akhlakul karimah anak di lingkungan keluarga nikah dini di Kecamatan Lubuk Besar Kabupaten Bangka Tengah. Adapun untuk menemukan solusi dari permasalahn diatas peneliti menggunakan metodologi sebagai berikut: dalam penelitian ini peneliti menggunakan pendekatan kualitatif fenomenologi adalah untuk mengamati gejala sosial, dan peran setiap individu untuk melakukan edukasi terhadap anak dan keluarga disetiap anggota masyarakat. Karena setiap pendidikan terdapat tujuan untuk membangun sebuah perilaku menjadi berakhlak yang baik diperlukan adanya pola empati dan peran yang memuat dan mengimplementasikan nilai-nilai edukasi atau bahwa setiap keluarga berhak untuk melakukan pendidikan dan bertanggung jawab mendidik anak dan keluarganya.

Adapun informan utama dalam penelitian ini adalah Adapun yang menjadi key informan dalam penelitian ini adalah guru Pendidikan Agama Islam dan guru TPA dan yang menjadi informan dalam penelitian ini adalah keluarga dan anak dari pelaku nikah dini, kemudian untuk informan pendukungnya adalah staff kecamatan Lubuk Besar guna mencari data-data mengenai gambaran umum Kecamatan Lubuk Besar. Dan teknik pengumpulan data pada penelitian ini yaitu: teknik observasi, wawancara dan dokumentasi. Kemudian teknik analisis yang peneliti gunakan yaitu: reduksi data, penyajian data dan verivikasi data. Hasil dari penelitian ini adalah pertama, pembentukan kepribadian akhlakul kaimah di lingkungan keluarga nikah dini tidak berjalan maksimal, karena keluarga sebagai pembentuk kepribadian anak belum memiliki bekal yang cukup dalam membangun rumahtangga sehingga para orangtua yang menikah dini belum bisa menerapkan segala sesuatu yang menjadi tanggungjawab sebagai orangtua dalam mendidik dan membesarkan anak. Kedua, sebagain besar anak memiliki adab dan akhlak yang kurang baik dan sebagian anak yang terlahir dari orangtua yang menikah dini memiliki kecacatan fisik dan psikologis seperti lahir dalam keadaan un-normal. Ketiga, diantara orangtua yang menikah dini sudah pernah menikah dua sampai tiga kali dikarenakan berbagai konflik dalam rumahtangga yang terjadi pada keluarga nikah dini yang disebabkaan karena ekonomi, maupun masalah yang lainnya.

Keempat, sebagian besar orangtua yang menikah dini lebih mempercayakan anaknya kepada para guru baik guru sekolah atau guru tempat anak mereka belajar mengaji dalam memberikan pendidikan keagamaan kepada anak Kelima, faktor penyebab terjadinya 
pernikahan dini di Kecamatan Lubuk Besar khusunya disebabkan karena faktor ekonomi, pendidikan, faktor orangtua dan pergaulan bebas yang terjebak dengan gaya pacaran yang salah. Walaupun dalam Islam tidak ada batasan umur ketika seseorang akan menikah, akan tetapi menikah dini sangat tidak dianjurkan karena akan berakibat fatal baik pada kehidupan rumahtangga atau anak dari pelaku nikah dini jika tidak dibekali dengan ilmu yang cukup dalam mendidik anak dan berumahtangga. Keenam, rata-rata yang menjadi observer adalah pelaku nikah dini dan berprofesi sebagai ibu rumah tangga. Ketujuh, dampak buruk dari pernikahan dini di Kecamatan Lubuk Besar diantaranya adalah depresi (gila), belum sanggup mengurus anak, konflik keluarga, perceraian dini, tekanan ekonomi, disharmoni keluarga, kehamilan yang berisiko, kepala keluarga sulit mencari pekerjaan karena sedikitnya pengalaman sebelum menikah. Dengan demikian sangat tidak dianjurkan untuk anak-anak muda zaman sekarang melakukan pernikahan dibawah umur. Karena tidak hanya akan berdampak pada dirinya dan keluarganya tetapi juga pada anak-anak pelaku nikah dini yang akan menjadi generasi penerus bangsa.

Keywords: Personalit, goodbehavior Children, Early Marriage

\section{A. Pendahuluan}

Perkembangan remaja merupakan fase peralihan menuju dewasa yang dimulai dari anak-anak. Pada perkembangan atau fase ini maka seseorang akan mengalamai perubahan yang banyak seperti perubahan hormon, fisik, ataupun mental. ${ }^{1}$ Mereka yang disebut dengan remaja ini bukanlah anak-anak, jika dilihat dari sikap mereka, bentuk badan, dan juga cara berfikir dan bertindak, akan tetapi juga bukan disebut dengan orang yang sudah dewasa yang memiliki cara berfikir yang matang. Sebagaimana pemikiran diatas seorang remaja akan dihadapkan tugas yang berbeda ketika mereka berada pada masa atau fase tersebut jika dibandingkan pada masa kanak-kanak. Karena setiap fase perkembangan seseorang yang telah memasuki usia remaja, mereka memiliki tugas-tugas yang harus dipenuhi pada masa perkembangan ini.

Jika seorang remaja mampu melewati tugas tersebut dengan mulus, maka seseorang tersebut akan mencapai tingkat kepuasan dan memiliki rasa kebahagiaan. Selain itu mereka dapat menentukan keberhasilan pada tugas di masa selanjutnya. Misalnya, tugas untuk bersikap mandiri secara emosional, mampu mempersiapkan

${ }^{1}$ Jose R.L. Batubara, 'Adolescent development (perkembangan remaja)', Sari pediatri, vol. 12, no. 1 (2016), pp. 21-9. Hal.21 
diri untuk memasuki dunia kerja, mampu mengembangkan kemampuannya, agar memenuhi kompetensi sebagai anggota masyarakat, mempersiapkan diri dalam menghadapi pernikahan dan sebagainya. ${ }^{2}$

Dengan demikian, seseorang yang masih tergolong dalam masa-masa remaja dan masih berada pada fase perkembangan maka dapat dikatakan bahwa mereka masih dalam mempersiapkan diri dan belajar serta masih mencari identitasnya. Maka, dari sini sangat perlu adanya dukungan baik dari orangtua, keluarga, masyarakat dan juga lingkungan sekitar. Karena para remaja pada fase ini, identitas mereka akan terbentuk dengan baik jika mereka berada dilingkungan keluarga dan masyarakat yang baik dan akan menjadi bekal bagi setiap remaja menuju tahap berikutnya yakni fase dewasa. Yang dikategorikan remaja dalam hal ini adalah usia 19 sampai 21 tahun dengan berbagai pertimbangan bahwa pada umur terseebut pembentukan identitas individu masih berlangsung. ${ }^{3}$ Sebagaimana disebutkan dalam buku Psikologi Pendidikan masa remaja dibagi atas 3 kategori yakni remaja awal berusia 13 sampai 15 tahun. Yang kedua masa remaja pertengahan berusia 15 sampai 18 tahun. Dan ketiga masa remaja akhir dengan usia 18 sampai 21 tahun. $^{4}$

Dari data Badan Pusat Statistik (BPS) adanya peningkatan angka persentase pernikahan dibawah umur dari 14,18\% menjadi 15,66\% pada tahun 2018 Kemudian, dari data KUA Kecamatan Lubuk Besar menunjukkan bahwa usia nikah khususnya bagi wanita yang terjadi pada masa sekolah menengah atas (SMA) atau setelah SMA yaitu usia 16-18 tahun sebanyak 9 pasang (27\%) dan pada usia 19-21 tahun sebanyak 8 pasang (24\%), data ini diambil selama 15 bulan dari bulan oktober 2017 sampai bulan Desember 2018. Selanjutnya, pernikahan yang terjadi pada umur dibawah 19 tahun mencapai $36 \%$ dari jumlah pernikahan 23 pasang. Data ini diambil dari bulan

${ }^{2}$ Sofia Retnowati, 'Remaja dan permasalahannya', Yogyakarta: Universitas (2011). Hal.9 dan 11

\footnotetext{
${ }^{3}$ Ibid. Hal.12

${ }^{4}$ Nyayu Khodijah, Psikologi Pendidikan (Jakarta : Raja Grafindo Persada, 2016). Hal.41
} 
januari sampai Agustus 2019.5 Bisa dibayangkan apa yang akan terjadi, jika seseorang masih dalam proses persiapan dan mencari identitas diri harus dihadapkan dengan tanggung jawab yang begitu besar, baik sebagai seorang kepala keluarga maupun sebagai seorang ibu yang memiliki tugas utama untuk mengurus anak. Tentu hal ini akan sangat mengkhawatirkan, baik bagi yang melakukan pernikahan, orangtua, masyarakat dan lingkungan sekitar jika pernikahan tersebut belum dibarengi dengan persiapan-persiapan yang matang. Pada dasarnya hukum Islam memang tidak memberikan batasan umur bagi seseorang yang akan menikah, akan tetapi sebagaimana yang telah diriwayatkan oleh Imam Taqiyuddin An-Nabhani dengan berlandaskan pada hadis Nabi yang artinya:

"Wahai para pemuda, siapa diantara kalian yang telah mampu', maka menikahlah! karena sesungguhnya menikah lebih menjaga pandangan dan menjaga kemaluan. Barang siapa yang belum mampu melaksanakannya, hendaknya ia berpuasa. Karena berpuasa akan menjadi pelindungnya" (Muttafaqun 'Alaih)'.?

Dari hadist tersebut dijelaskan bahwasannya adanya perintah menikah bagi para pemuda dengan syarat harus memiliki kesiapan, adapun 3 hal yang harus dipersiapkan yaitu: kesiapan ilmu, harta, dan kesiapan fisik (jasmani dan rohani). Jika dilihat dari hukum asalnya pernikahan memang diperbolehkan, akan tetapi bukan berarti arti diperbolehkan tersebut bersifat mutlak untuk semua perempuan bagaimanapun keadannya. Karena pada sebagian perempuan ada beberapa kondisi yang dianjurkan dan akan lebih baik jika tidak menikah pada usia dini. Karena ada beberapa ketentuan yang harus diperhatikan jika seseorang akan memutuskan untuk menikah diusia yang muda atau melakukan pernikahan dini walaupun dengan tujuan

\footnotetext{
${ }^{5}$ Data didapat dari KUA Lubuk Besar 2 November 2019

${ }^{6}$ Mampu, baik secara lahir maupun batin

${ }^{7}$ Tim Ulin Nuha, Fiqh Munakahat (Sukoharjo : Kiswah Media, 2018). Hal. 18
} 
yang baik misalnya akan tidak terjadi sesuatu yang kurang baik kedepannya, sebagaimana yang telah diungkapkan dari berbagai kalangan bahwa banyak hal negatif yang akan muncul jika pernikahan diusia muda tetap dilakukan. Ketika seseorang akan memutuskan menikah diusia muda ada beberapa hal yang harus diperhatikan yang pertama perempuan harus mempersiapkan diri secara fisik. Kedua, jika seorang perempuan umurnya sangat belia, akan lebih baik jika memiliki calon suami yang tidak terpaut jauh dengan usianya dengan tujuan agar mereka dapat melanggengkan pernikahan dan kehidupan berumahtangga, terkecuali jika ada sebab yang dibenarkan. ${ }^{8}$

Kemudian jika dilihat dari aspek kesehatan dan psikologis, sangat wajar jika banyak yang merasa khawatir tentang adanya pernikahan yang dilakukan ketika seseorang masih dibawah umur karena akan mempengaruhi keadaan fisik maupun keturunan mereka dan juga pada perkawinan tersebut akan lebih rentan dengan adanya konflik yang pada akhirnya akan berakhir pada perceraian, yang disebabkan karena minimnya persiapan dan mental serta kedewasaan dari kedua pasangan, karena dengan usia yang masih belia mereka harus dibebani dengan berbagai tanggungjawab yang begitu besar sebagai suami istri tanpa adanya bekal keilmuan sebelumnya, maka psikologis keduanya bisa dikatakan belum siap jika dibandingkan dengan calon pengantin yang telah berusia dewasa dan meiliki keilmuan yang matang. Adapun usia untuk hamil dan melahirkan sebagaimana diungkapkan oleh Badan Koordinasi Keluarga Berencana Nasional (BKKBN) yaitu 20-30 tahun, lebih atau kurang dari usia tersebut akan beresiko. Kemudian seorang perempuan dikatakan siap melahirkan dan mempunyai keturunan dilihat dan ditentukan pada tiga hal, yakni: kesiapan fisik, kesiapan mental, emosi, psikologis ibu, sosial kemasyarakataan, dan ekonomi. ${ }^{9}$

\footnotetext{
${ }^{8}$ Dwi Rifiani, 'Pernikahan dini dalam perspektif hukum islam', De Jure: Jurnal Hukum dan Syariah, vol. 3, no. 2 (2011).

9 Anonim, Kesiapan Kehamilan (Http://Www.BKBN.Co.Id) Hindari Kawin Muda Agar Hidup Bahagia (2005), diakses tanggal 22 november 2018).
} 
Anak merupakan perwujudan antara cinta dan kasih sayang suami istri. Karena setiap orang yang telah melangsungkan pernikahan ingin mempunyai keturunan. Dalam Islam seorang anak tidak boleh disia-siakan. karena pada hakikatnya anak merupakan amanah dari Allah swt. yaitu kepercayaan yang diberikan oleh Allah kepada semua orangtua tidak boleh disia-siakan. Adapun amanah yang diberikan Allah swt ini semenjak seorang anak masih berada dalam janin seorang ibu, kemudian anak tersebut dilahirkan kemudian tumbuh menjadi dewasa, bahkan sampai anak tersebut mampu untuk membangun rumahtangga (beristri bagi laki-laki dan bersuami bagi anak perempuan). Dengan demikian amanah orangtua akan berakhir ketika anak mereka sudah berkeluarga.

Seorang anak merupakan permata dan belahan jiwa bagi kedua orangtuanya, karena anak merupakan tumpuan harapan orangtua di hari tuanya. Jika diibaratkan sebuah permata maka dia akan dirawat dengan sepenuh hati, dilindungi dari setiap bahaya, diawasi dan diberikan benteng yang dapat dijadikan pengaman agar dia tidak bisa tercemar dari setiap hal yang sifatnya negatif dan berbahaya, serta dibersihkan dari virus-virus hati. Maka pribadi anak akan bergaantung pada pendidikan yang diberikan keluarganya, dan terutama adalah pendidikan yang diberikan oleh kedua orangtuanya.

Keluarga merupakan sebuah lingkungan pendidikan bagi seorang anak sejak mereka terlahir didunia. Juga ketika anak mereka tumbuh menjadi seorang yang telah dewasa orangtua masih memiliki hak untuk memberikan nasihat-nasihat yang baik kepada anak mereka. Selain itu sebuah keluarga disebut juga dengan institusi yang banyak memiliki nilai. Karena orangtua adalah orang yang memiliki tanggungjawab dalam mewariskan nilai yang baik juga nilai yang positif seperti dalam masalah Agama, sosial, etika, adab, moral, serta akhlak kepada setiap anak dengan tujuan dan harapan dari orangtua agaar nilai-nilai tersebut dapat memberikan pengaruh yang baik dan kuat dalam membentuk kepribadian seorang anak, sehingga 
sikapnya maupun perilakunya tidak bersifat bebas akan tetapi mereka dapat mengendalikannya melalui nilai-nilai yang ahsan yang ditanamkan oleh orangtua. ${ }^{10}$

Kepribadian merupakan sifat asli yang dibawa seseorang dan suatu pola tingkahlaku yang melekat juga menjadi khas bagi seseorang tersebut. adapun disebut dengan kepribadian meliputi cara berpikir, perasaan dan gerak hati, usaha yang dilakukan, tanggapan terhadap kesempatan yang diberikan oranglain, respon dari tekanan dan cara yang digunakan orang tersebut sehari-harinya dalam melakukan interaksi dengan orang lain. Jika semua unsur dari kepribadian ini dilakukan oleh seseorang secara berulangkali dan memiliki khas serta bersifat dinamis maka inilah yang disebut dengan gaya kepribadian. ${ }^{11}$

Dalam hidup ini kepribadian adalah sesuatu yang sangat penting, karena kepribadian akan menentukan sikap dan identitas seorang individu. Adapun permasalahan yang dihadapi pendidikan didunia saat ini yaitu mengenai karakter dan perilaku siswa. Banyaknya kekarasan, adanya tawuran dan perkelahian antar siswa dan juga pelecehan seksual yang menjadi sorotan dunia pendidikan yang saat ini kehilangan jati dirinya dan karakter sebagai sebuah institusi pendidikan. Adapun salah satu cara yang bisa digunakan untuk mengurangi permasalahan tersebut yakni dengan menanamkan nilai-nilai akhlakul karimah dalam diri peserta didik, dengan tujuan dapat membangun dan menghasilkan generasi yang mempunyai karakter dan budi pekerti yang baik. Dan salah satu cara yang bisa ditempuh dalam menanamkan nilai tersebut adalah melalui proses pendidikan dengan harapan kualitas generasi muda-mudi para siswa dan siswi dapat berkembang dalam berbagai aspek dan juga berpengaruh dalam berkurangnya karakter siswa yang kurang baik saat ini.

Salah satu aspek penting dalam pendidikan Islam adalah pendidikan akhlakul karimah dan budi pekerti, karena pendidikan tersebut adalah ajaran yang terpenting dalam proses pendidikan. Jika individu pada masa kecilnya jauh dari

\footnotetext{
${ }^{10}$ Syaiful Bahri Djamarah, Pola Asuh Orang Tua dan Komunikasi dalam Keluarga (Jakarta : Rineka Cipta, 2017). Hal.28-37

${ }^{11}$ Sjarkawi, Pembentukan Kepribadian Anak (Jakarta: Bumi Aksara, 2015). Hal.13
} 
akhlak maka tidak ada keraguan jika dia sudah memasuki usia dewasa akan salah dalam pergaulan. Dengan demikian, begitu pentingnya memberikan pendidikan akhlak kepada anak sejak kecil.

Kemudian jika dilihat dari kenyataan yang ada pada masa sekarang ini, banyak guru yang mengeluh bahwa generasi muda-mudi saat ini berani dan melawan kepada orangtua ataupun kepada gurunya berkhlak yang kurang baik dan tidak memiliki sopan santun kepada orang yang lebih tua. Kurangnya pendidikan dan penenaman akhlakul karimah kepada para siswa menjadi salah satu penyebab melencengnya pergaulan anak-anak ini, dengan demikian sangatlah penting seorang guru mendidik dan memberikan keteladanan yang baik bagi para peserta didiknya. Karena sangat besar pengaruh seorang guru terhadap muridnya, akan tetapi seorang guru harus melakukan koordianasi dengan keluarga dan memperhatikan lingkungannya agar para guru dapat membina dan mengarahkan para siswanya menjadi pribadi dan genarasi yang baik yang berbudi pekerti dan berakhlakul karimah.

Selain itu, peran keluarga dalam pembentukan kepribadian seorang anak sangatlah penting sebagai upaya untuk mengembangkan kepribadian anak, terutama adalah peran orangtua. Lingkungan terdekat yakni seorang ayah dan ibu akan sangat mempengaruhi perkembangan anak terutama terutama pada bayi yang baru lahir. Karena dari lingkungan tersebut emosi dan interaksi dengan oranglain serta belajar untuk mengenal diri sendiri bagi seorang anak akan dimulai. Dari sinilah emosi seorang anak akan terpengaruhi dari bagaimana orangtua mengasuh dan mendidik anak mereka. Karena akan ada setiap nilai yang tertanam, diikuti dan dicerna oleh seorang anak. Perkembangan emosi juga pembentukan kepribadian seorang anak sangat bergantung pada perlakuan yang diberikan setiap anggota keluarga karena segala sesuatunya akan direkam dan diikuti oleh anak. ${ }^{12}$

12 Yuli Setyowati, Pola komunikasi keluarga dan perkembangan emosi anak (studi kasus penerapan pola komunikasi keluarga dan pengaruhnya terhadap perkembangan emosi anak pada keluarga Jawa) (2013). Hal.67-68 
Tanda dari sebuah masalah psikososial yang terdapat dalam diri anak yaitu adanya gangguan-gangguan yang muncul pada anak misalnya kurangnya sosialisasi dengan oranglain, kurang berinisiatif, cenderung diam dan memiliki ketakutan dalam mengungkapkan pendapat, akan sangat bahaya dan memiliki dampak yang kurang baik terhadap tumbuh kembang anak jika semua gangguan ini terjadi secara terus menerus dengan sebab keinginan seorang anak untuk bergerak aktif tidak tersalurkan dengan benar, dikarenakan ada hambatan yang menghalangi mereka hingga pada akhirnya membuat seorang anak semakin meresa bersalah. Maka rasa bersalah tersebut memiliki dampak yang sangat tidak baik untuk perkembangan kepribadian anak, banyak kemungkinan yang akan terjadi seperti menjadi anak yang sangat pendiam atau nakal, dan lingkungan keluarga merupakan salah satu faktor yang menyebabkan gangguan perkembangan psikososial anak. ${ }^{13}$

Di Desa Lubuk Besar sendiri, beberapa kasus yang semisal juga terjadi, salah satunya yakni berdasarkan keterangan salah satu guru SD di Lubuk Besar yaitu Ibu Mayangsari, menyatakan bahwasannya 30\% dari siswa di sekolah tersebut dalam satu kelas ada yang mengalami konsentrasi belajar yang tidak maksimal ketika belajar di kelas, kecerdasan yang berada dibawah rata-rata, dan kenakalan yang melampaui batas. Kemudian, setelah dilakukan penelusuran ternyata, sebagian besar orangtua dari anak-anak tersebut adalah pelaku pernikahan dini. ${ }^{14}$ Selain itu peneliti juga menemukan fakta bahwa anak-anak yang orangtuanya melakukan pernikahan dini pernah menikah dua sampai tiga kali (kawin-cerai). ${ }^{15}$ Memang benar tidak semua anak dengan beberapa masalah tersebut penyebabnya adalah pernikahan dini (usia ibu yang belum maksimal untuk menikah ataupun hamil), bisa saja karena lingkungan tempat anak tersebut tinggal, pengaruh dari teman sebayanya ataupun faktor yang lainnya, akan tetapi lingkungan keluarga terutama seorang ibu menjadi

13 Heri Saputro and Yuventri Otnial Talan, 'Pengaruh Lingkungan Keluarga Terhadap Perkembangan Psikososial Pada Anak Prasekolah', Journal Of Nursing Practice, vol. 1, no. 1 (2017), pp. 1-8.Hal.2

${ }^{14}$ Observasi pendahuluan di Kecamatan Lubuk Besar 5 Oktober 2019

${ }^{15}$ Observasi pendahuluan di Kecamatan Lubuk Besar 22 Juni sampai 5 Juli 2020 
faktor utama dalam mendidik dan mengasuh anak mereka saat berada dalam lingkungan keluarga.

Sebagaimana telah dijelaskan dalam penelitian Malehah bahwasannya kualitas janin dan perkembangan anak sangat ditentukan oleh usia ibu ketika hamil. Akan ada resiko berbahaya jika hal tersebut dilanjutkan dan agar tidak merusak generasi dan keturunan selanjutnya maka hal tersebut harus segera dihentikan. ${ }^{16}$ Tidak hanya aspek dari segi fisik bahkan menurut Mangoenprasodjo, yang juga dapat mempengaruhi usia ibu hamil, sebab ibu yang usianya masih tergolong remaja sesungguhnya belum ada kesiapan untuk menjadi seorang ibu dan belum memiliki keterampilan serta ilmu yang cukup dalam mengasuh anak. Kebanyaka ibu muda akan banyak memperlihatkan bukan sifat keibuannya tetapi sifat keremajaan. ${ }^{17}$ Perubahan kesiapan menjadi peran sebagai orangtua sangalah diperlukan, dengan tujuan agar pelaksanaan tugas dalam tercapai untuk itu sangat diperlukannya kesiapan yang tinggi dari orangtua dalam mendidik anak dari kecil. ${ }^{18}$

Berpengaruhnya usia dalam berkeluarga memiliki pengaruh besar terhadap perkembangan mental anak karena seorang ibu belum memiliki kemampuan untuk menyelesaikan masalah yang dihadapi dan memiliki emosi yang tidak stabil artinya masih sering muncul sifat keremajaannya, juga akan ada pengaruh yang tidak baik ketika seseorang melakukan pernikahan diusia muda. Pengaruh tersebut diantaranya kecerdasan yang kurang pada anak yang lahir pada ibu yang masih remaja. Sebab seorang ibu belum mempunyai kesiapan untuk memberikan rangsangan mental kepada anak mereka. Cara seorang ibu berbicara pada anaknya juga akan mempengaruhi perkembangan bahasa anak kelak. Pemberian mainan dapat menjadi

16 Siti Malehah, Dampak psikologis pernikahan dini dan solusinya dalam perspektif bimbingan konseling Islam (studi kasus di desa Depok kecamatan Kalibawang kabupaten Wonosobo) (IAIN Walisongo, 2010).

${ }^{17}$ A. Setiono Mangoenprasodjo, 'Pengasuhan anak di era internet', Yogyakarta: ThinkFresh (2004).

${ }^{18}$ Rizqiana Ekasari, Hubungan antara Kesiapan Perubahan Peran sebagai Orangtua dengan Tingkat Depresi pada Ibu Postpartum Usia Remaja”. (Universitas Brawijaya, 2013). 
rangsangan mental yang baik untuk Aspek kecerdasan non bahasa dan kebanyakan stimulan mental tersebut tidak diberikan oleh ibu yang remaja. ${ }^{19}$

Dengan demikian keterlibatan orangtua maupun anggota dalam keluarga terutama ibu yang mengasuh anak mereka perlu memberikan alat-alat untuk anak bermain, mengajak anak untuk bersosialisasi agar stimulus mental tersebut dapat berkembang dengan baik.. ${ }^{20}$ bertambahnya skil dalam sebuah struktur dan fungsi dari tubuh dalam arti yang lebih komoleks dengan bentuk yang lebih teratur merupakan perkebangan dari proses yang matang. ${ }^{21}$ Terbentuknya dasar dari kepribadian dalam diri manusia, kemampuan untuk berpikir dan mengindera, kemampuan untuk bertingkahlaku, bersosialisasi, kemampuan dalam berbahasa terjadi pada anak yang berusia dibawah lima tahun (balita) yang disebut juga dengan masa emas atau golden age. Masa inilah masa yang akan menentukan hasil proses perkembangan anak berikutnya dan merupakan masa kritis bagi anak.

Maka, bekal keilmuan dalam mendidik anak dan berumahtangga sangalah diperlukan bagi orangtua terutama seorang ibu dalam mendidik anak. Faktanya sebagian anak remaja di Kecamatan Lubuk Besar telah melakukan pernikahan dan memiliki anak. Tentu pernikahan tersebut terjadi tidak hanya karena satu sebab tapi karena berbagai hal seperti ekonomi, pendidikan, bahkan ada yang menikah karena kasus MBA (Married By Accident)

\section{B. Data Pernikahan Dini di Lubuk Besar Kabupaten Bangka Tengah}

Kecamatan Lubuk Besar merupakan salah satu kecamatan yang ada di Kabupaten Bangka Tengah. Kecamatan Lubuk Besar terdiri dari 9 desa diantaranya: Desa Lubuk Besar, Desa Lubuk Pabrik, Desa Lubuk Lingkuk, Desa Batu Beriga, Desa Perlang, Desa Kulur, Desa Belimbing, Desa Trubus, dan Desa Kulur Ilir. Kecamatan Lubuk Besar memiliki luas $26.535 \mathrm{~km}^{2}$ dengan kepadatan penduduk

\footnotetext{
${ }^{19}$ Elizabeth B. Hurlock, 'Psikologi perkembangan: suatu perkembangan sepanjang rentang kehidupan', Edisi Keenam, Jakarta: Penerbit Erlangga (2004).

${ }^{20}$ Ibid.

${ }^{21}$ Soetjoningsih, Tumbuh Kembang Anak (Jakarta: ECG, 1998).
} 
47,98 jiwa. Adapun mata pencaharian penduduk setempat berasal dari perladangan, perkebunan, peternakan, pertambangan, kerajinan, dan industri. Untuk pendidikan, di Kecamatan Lubuk Besar terdapat 17 Sekolah Dasar, 2 SMP, 1 MTs, dan 1 SMA. ${ }^{22}$ Dari data tersebut penulis juga mendapatkan data pernikahan dini di Kecamatan Lubuk Besar sebagaimana grafik dibawah ini:

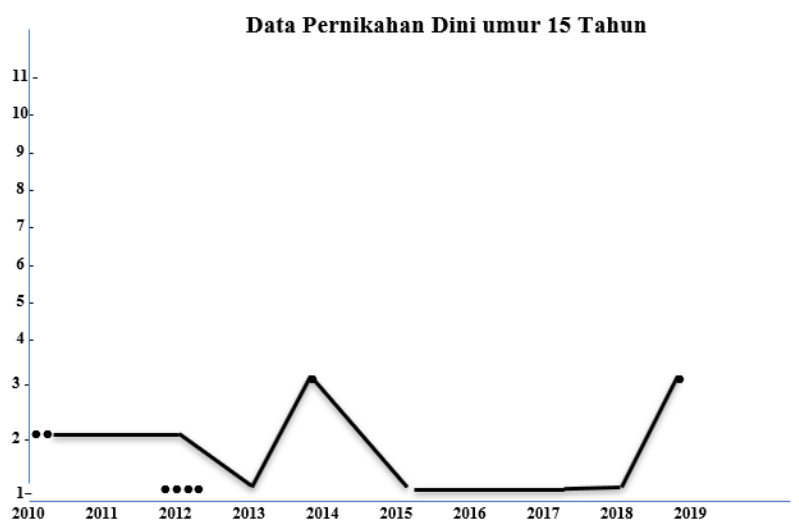

Data Pernikahan Dini umur 16 Tahun

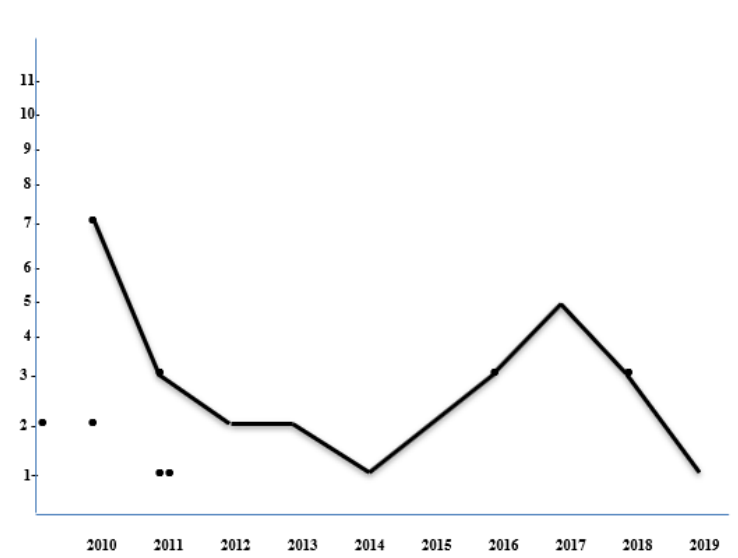

${ }^{22}$ Data diambil dari kantor kecamatan Lubuk Besar 
Data Pernikahan Dini umur 17 Tahun
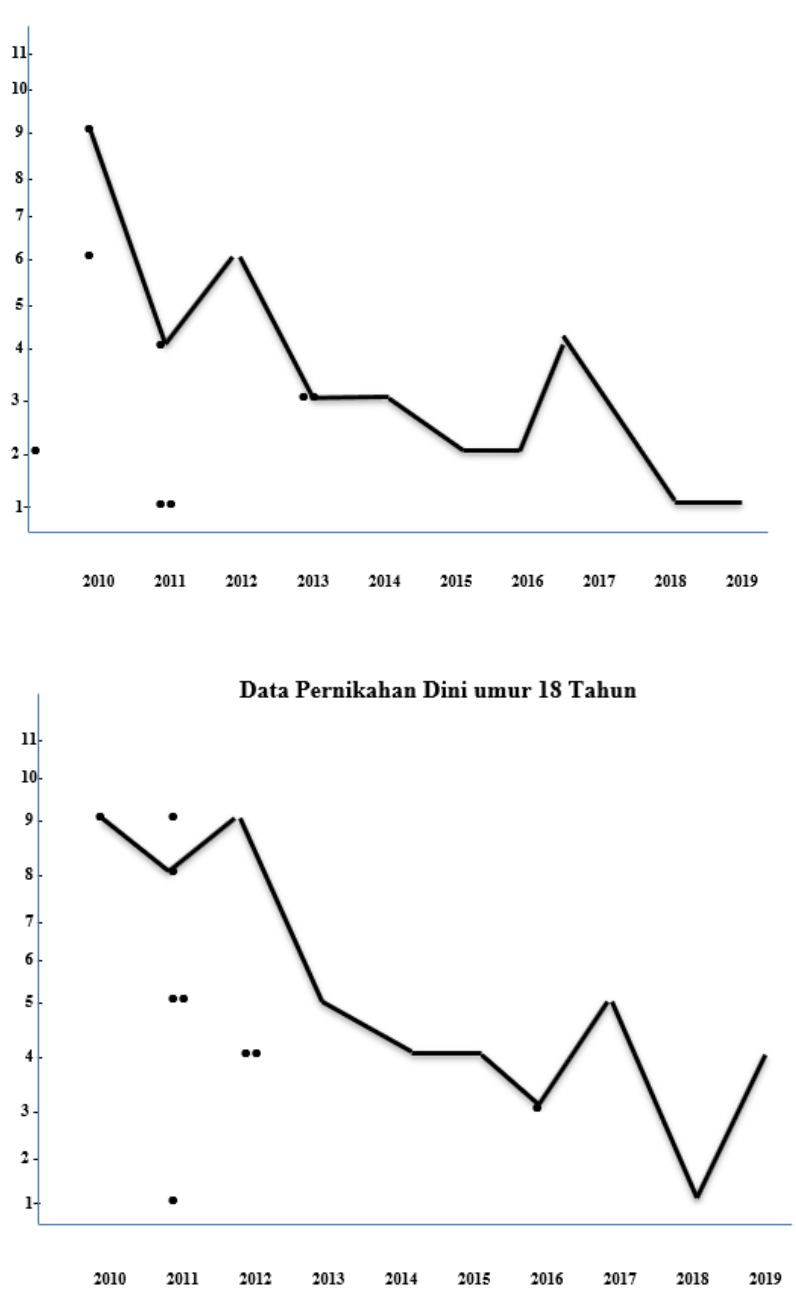

Dari data di atas, penulis menganalisis bahwasannya masih banyak anakanak khususnya di Kecamatan Lubuk Besar yang melakukan pernikahan dini. Selain itu pemaparan mengenai pelaku yang menikah dini juga diperkuat dengan adanya data dari Badan Pusat Statistik (BPS) adanya peningkatan angka persentase pernikahan dibawah umur dari $14,18 \%$ menjadi $15,66 \%$ pada tahun 2018 Kemudian, dari data KUA Kecamatan Lubuk Besar menunjukkan bahwa usia nikah khususnya bagi wanita yang terjadi pada masa sekolah menengah atas (SMA) atau setelah SMA 
yaitu usia 16-18 tahun sebanyak 9 pasang (27\%) dan pada usia 19-21 tahun sebanyak 8 pasang (24\%), data ini diambil selama 15 bulan dari bulan oktober 2017 sampai bulan Desember 2018. Selanjutnya, pernikahan yang terjadi pada umur dibawah 19 tahun mencapai $36 \%$ dari jumlah pernikahan 23 pasang. Data ini diambil dari bulan januari sampai Agustus 2019. ${ }^{23}$ Bisa kita bayangkan apa yang akan terjadi, jika seseorang masih dalam proses persiapan dan mencari identitas diri harus dihadapkan dengan tanggung jawab yang begitu besar, baik sebagai seorang kepala keluarga maupun sebagai seorang ibu yang memiliki tugas utama untuk mengurus anak. Tentu hal ini akan sangat mengkhawatirkan, baik bagi yang melakukan pernikahan, orangtua, masyarakat dan lingkungan sekitar jika pernikahan tersebut belum dibarengi dengan persiapan-persiapan yang matang.

Berdasarkan UU tentang batas usia minimal seseorang menikah yang telah ditetapkan dalam UU No.16 Tahun 2019 tentang pernikahan yang telah disahkan bahwasannya jika seseorang akan melangsungkan pernikahan maka pernikahan tersebut harus dilakukan saat seseorang sudah mencapai umur minimal 19 tahun, tentu ketetapan tersebut sudah mempertimbangkan beberapa aspek, baik psikologi, emosional, ekonomi maupun dari aspek kesehatan. Banyak faktor yang menjadi penyebabnya. Sebagaimana telah diungkapkan didalam buku pernikahan dini karya Lauma Kiwe diantara faktor yang menyebabkan terjadinya pernikahan dini adalah sebagai berikut: faktor pendidikan, ekonomi, orangtua dan keluarga, media massa, adat istiadat, dan pergaulan bebas, dari beberapa penyebab terjadinya pernikahan dini tersebut, di Lubuk Besar sendiri ada beberapa kasus yang terjadi akibat pernikahan dini. Diantara pelaku nikah dini di Kecamatan Lubuk Besar mereka menikah karena faktor pendidikan dan tidak melanjutkan sekolah dikarenakan orangtua tidak mampu untuk membiayai sekolah anaknya,

${ }^{23}$ Data didapat dari KUA Lubuk Besar 2 November 2019

90 | EDUGAMA Vol. 7 No. 1 Juli 2021 


\section{Metode yang digunakan dalam pembentukan kepribadian akhlakul karimah anak di lingkungan keluarga nikah dini di Kecamatan Lubuk Besar Kabupaten Bangka Tengah}

Dalam membentuk kepribadian akhlakul karimah anak khususnya di lingkungan keluarga nikah dini di Kecamatan Lubuk Besar sebagaimana hasil wawancara dan observasi diatas, anak-anak dari keluarga nikah dini dalam mendapatkan nilai-nilai akhlakul karimah, mereka dapatkan dari pendidikan formal dan informal seperti sekolah dan TPA. Banyak metode yang bisa digunakan dalaam pembentukan kepribadian akhlakul karimah diantara metode tersebut aialah, metode uswah atau keteladanan, metode nasehat, metode qishah atau cerita, metode pembiasaan, metode hukuman dan pemberian hadiah. Untuk mengetahui hal tersebut pada penilitian ini penulis melakukan wawancara dan observasi kepada beberapa guru PAI dan guru TPA di Kecamatan Lubuk Besar terutama para guru yang mengajar anak-anak dari pelaku nikah dini, sebagai berikut:

Sebagaimana wawancara dengan Ibu Siti selaku guru PAI di SDN 1 Lubuk Besar dalam mengajar PAI disekolah kepada anak-anak, Ibu Widi menggunakan metode keteladanan, Qisah, metode pembiasaan, hukuman dan pemberian hadiah sebagaimana diungkapkan oleh Ibu Siti sebagai berikut:

"Jika ada anak yang belum menurut maka Kita kasih sanksi dan beri arahan, nasehat dan juga semangat untuk selanjutnya anak tersebut harus mengerjakan tugas. Kita kasih arahan yang baik kalo sikap seperti itu tidak baik. Kalo anak nakal jangan dipukul atau dikerasin tapi dilembutin dengan cara berbicara dengan lembut maka anak tersebut akan menurut dan tidak membantah dengan guru. Jika perlu untuk dikonsultasikan dengan orangtua kita panggil orangtuanya, namun jika masih bisa diatasi kita tidak perlu membawa orangtua. Iya tetapi hadiah disini bukan berupa benda tetapi

berupa pujian untuk menyemangatinya. Kegiatan yang biasa dilakukan ya Sholat dhuha setiap pagi, mengaji setiap pagi, berdoa sebelum masuk kelas. Pasti ada, saya selalu menyampaikannya melalui cerita-cerita pendek, yang 
diakhir cerita itu ada pesan moral yang bisa dipelajari oleh anak-anak. Dengan memberikan contoh dalam kegiatan sehari-hari mereka sehingga mereka dapat mengaplikasikannya langsung. Cukup besar pengaruhnya karena itu sangat berguna dan selalu ada dalam kehidupan sehari-hari mereka"24 $^{24}$

Lain halnya dengan bapak usman yang menggunakan metode pembiasaan, hukuman dan pemberian hadiah dalam pembentukan kepribadian anak, bapak Usman mengungkapkan bahwa:

"Disini kegiatan keseharaiannya tilawah surat pendek sepuluh menit sebelu jam pelajaran dimulai. Ada materi yang dipelajari mengenai jujur, amanah, itu ada. Kalau saya lebih ke penjelasan dan contoh dalam kehidupan seharihari. Kalau saat ini belum terlalu signifikan pengaruhnya, karena semua itu kan butuh proses tidak bisa instan, karena yang saya lihat selama ini perubahan pada anak yang paling menonjol adalah tidak membuang sampah sembarangan, itu sudah mulai terlihat karena kita selalu biasakan, dan memberikan penyampaian yang berulang. Ditegur dan dihukum sesuai dengan ketentuan yang berlaku. Jika ada anak yang belum menurut hal yang saya lakukan sebagai guru adalah memberikan kebebasan untuk dirinya, karena menurut saya setelah saya memberikan hukuman dengan memberikan kebebasan untuk anak tersebut justru anak tersebut diam dan takut. Yang mempengaruhi akhlak anak adalah faktor lingkungan, teman dan keluarga. Komunikasi pasti ada, apalagi jika anak tersebut membahayakan teman-temannya pasti kami panggil orangtuanya misalnya anak berkelahi. Tentu saya berikan hadiah karena untuk tingkat semangatnya lebih tinggi, bisanya hadiah yang saya berikan buku, pulpen, pensil" 25

\footnotetext{
${ }^{24}$ Siti Nurkhotimah, Guru Pendidikan Agama Islam, Desa Lubuk Besar, 23 September 2020

${ }^{25}$ Usman, Guru Pendidikan Agama Islam, Wawancara .Dusun B2, 24 September 2020
} 
Selain itu Ibu Widi juga mengungkapkan hal yang senada dengan bapak usman dan ibu siti dalam pembentuka kepribadian akhlakul karimah siswa, Ibu Widi menggunakan metode nasehat, hukuman, hadiah dan metode cerita dan juga keteladanan dalam menyampaikan materi pembelajarannya kepada para siswa dan membentuk kepribadian yang baik. Ibu Widi mengatakan bahwa:

"Biasanya saya tegur mbak, kalau gak gerjakan pr langsung berdiri didepan kelas. Karena sebelum memberikan hukuman itu kami ada perjanjian terlebih dahulu diawal pertemuan. Jadi kita kayak seperti bikin aturan. Misalnya yang gak piket kelas hukumannya membuang sampah ketika pulangsekolah, kemudia yang tidak mengerjakan pr berdiri didepan sampai jam pelajaran selesai seperti itu. Kemudian kalau gak nurut biasanya saya kasih kayak sedikit ancaman gitu mb ayo yang tidak nurut nanti saya telponkan orangtuanya biar dijemput langsung dan tidak boleh sekolah.Alhamdulillah, semakin kesini gak ada lagi yang jika dinasehati gak nurut gitu. Ya itu tadi mbak pertama saya nasehati dulu kalau gak nurut saya bawa kekantor saya telponkan orangtuanya. Menurut saya banyak aspek yang bisa mempengaruhi akhlak anak, bisa dari keluarga lingkungan ataupun temanya. Nah yang paling utama akhlak anak itu akan sangat berpengaruh karena faktr keluarga terutama bagaimana seorng ibu mendidik anaknya dari kecil. Kalau kisalnya anak itu di didik dengan Agama dari kecil ditanamkan nilai-nilai kebaikan insyaAllah nanti ketika sudah besar dia tidak akan salah dalam bertindak baik bertindak terhadap teman-temannya ataupun dengan keluarga an lingkungan sekitarnya karepa apa, karena dia sudah memiliki bekal-bekal kebaikan dalam dirinya. Pasti akan saya berikan hadiah mbak, walaupun reward yang diberikan itu tidak harus berupa hadiah yang nyata, ya paling tidak tepuk tangan pujian seperti pinter, hebat itu sering mbak. Kalau hadiah yang nyata seperti makanan, alat tulis biasanya saya berikan ketikaselesai ulangan atau semester. Kalau ditempat saya 
mengajar mbak jadi anak-anak itu pagi-pagi sholat dhuha berjamaah kemudian ada seperti kultum buat aanak-anak misalnya tentang kejujuran, doa. Nah disini kami sebagai guru sangat mengutamakan keteladanan dan contoh yang baik mbak, karena anak pada masih sekolah dasar sering melihat apa-apa yang dilakukan gurunya, jadi semaksimal mungkin kami selalu memberikan keteladanan yang baik kepada mereka, misalnya selalu mengambil wudhu duluan, tilawah ketika waktu istirahat, tidak membuang sampah sembarangan. Jadi akan lebih menurut ketika kita memberikan nasehat kepada mereka. Saya sampaikan dengan mengaitkan contoh dala kehidupan sehari hari dan biasanya saya menyampaikan nya dengan sedikit cerita-cerita pendek mbak, dan yang pasti dengan bahasa anakanak.Misalnya gini, jujur. Kalian kalau dirumah sering bohong gak sama orangtuanya, bohong apa bu ? bohong minta uang untuk bayar buku padahal untuk beli mainan hayo ngaku. Yang gak ngaku nanti dosanya tambah besar, tambah banyak, tambah tinggi nahhh, mau gak banyak dosanya. Gak mau bu. Nah kadang pas kita ngejelasin itu ada anak yangjujur mbak tiba-tiba bu saya kemarin g-gini-gitu dst. Iya, ade ini sudah bagus mau jujur. Hebat. Tapi jangan lupa kalau kita bhong sama oragtua maka segera jujur, biar apa biar uang yang diberikan orangtua kalian jadi bermanfaat, dan jadi daging gak jadi ulat dan racun didalam perut kalian"26

Selain belajar disekolah anak-anak dari pelaku dikah dini ini juga ada yang disekolahkan di TPA dalam mendidik ilmu agama dan belajar Al-Quran karena di TPA khususnya yang ada di Kecamatan Lubuk Besar anak-anak tidak hanya diajarkan mengaji iqro' atau Al-Qur'an saja tetapi para guru juga mengajarkan bagaimana menanamkan kejujuran, adab dan akhlak yang baik kepada para muridnya melalui kegiatan kultum dan tanya jawab. Hal ini sebagaimana di

${ }^{26}$ Widi, Guru Pendidikan Agama Islam, Wawancara .Dusun C2, 24 September 2020 
ungkapkan oleh Pak Asel selaku guru TPA Nurul Qomar dusun B1 beliau mengungkapkan bahwa dalam mendidik anak-anak beliau menggunakan beberapa metode diantara qishah (cerita), keteladanan, nasehat, hukuman, pembiasaan, hadiah "Dihukum dan pasti hukuman tersebut adalah hukuman yang sifatnya mendidik misalnya saya suruh menghafal terlebih dahulu baru boleh ikut belajar, Anak disni kebanyakan Susah diatus, lari kesana-sini, makanmakanan tumpah. Tapi kita sebagai guru ya harus sabar, dan pada akhirnya yang membersihkan ya gurunya semua, tapi yang saya lihat sebenrnya mereka itu baik semua, karena ketika saya membersihkan makanan yang tumpah justru anak-anak bantuin saya. Dengan pendekatan, nasehat baikbaik, karena anak itu semakin menurut jika diberikan nasehat dengan baikbaik, karena disini kita semua memiliki satu pegangan jika ada anak yang bermasalh maka kita sentuh hatinya dengan kelembutan bukan dengan kekerasan. Karena tipe anak-anak semakin kita kerasi maka mereka akan semakin membenrontak. Sering mbak kalau hadiah walaupun hadia itu hanya berupa pujian, tepuk tangan, makanan seperti permen jajaja, kemudian pensil penghapus kadang-kadang ada juga walaupun tidak setiap hari. Tujuan saya memberikan itu seua agar anak lebih semangat dan selalu semnagt ketika belajar di TPA ini, dan yang pasti mereka lebih nyaman dan juga tidak merasa bosan ketika belajar di tempat mengaji. Dan tujuannya agar mereka terbiasa berada ditempat-tempatt yang baik dan kegiatan yang baik.Kegiatan disini ada mengaji, belajar kosakata bahasa Arab, dhalat dhuha juga ada kemudian kegiatan kultum sebelum mulai pembelajaran biasanya saya lakukan setelah berdoa dan sebelum memulai aktivitas mengaji.Banyak hafalannya mbak disini, tapi hafalannya kami buat menyenangkan, setelah guru mencontohkan dan mengucapkannya secara berulang anak-anak disuruh menempelkan gambar atau menyusun kata bahasa Arab jadi hafalan anak-anak akan lebih lengket. Selain itu kami juga ada hafalan surat-surat pendek. Alhamdulillah pengaruhnya luar biasa, 
karena yang saya tahu juka kita memberikan teladan yang baik kepada anakanak maka anak-anak juga akan menirukan perilaku guru-gurunya. Tidak semua, tapi kita selalu memberikan semangat untuk mereka. Memintanya hafalkan baru boleh pulang, walaupun hanya satu ayat, atau satu kosakata bahasa Arab saja"27

Selanjutnya hal senda juga diungkapkan oleh Ibu Ayu, beliau juga menggunakan metode yang tidak jauh beda dengan pak Asel, Ibu Ayu menggunakan metode pembiasaan dan nasehat dalam mengajar di TPA Al-Ikhlas Dusun Melingai Kecamatan Lubuk Besar Ibu Ayu mengungkapkan bahwa:

"Kegiatan disini seperti Berdoa sebelum belajar membaca surat pendek, kemudian shlata ashar berjamaah sebelum pulang. Ada kegiatan lain seperti menghafal surat pendek biasanya satu hari satu ayat nambahnya. Kegiatan menghafalnya setiap hari tapi kalau ada yang belum hafal biasanya saya ulang terlebih dahulu secara bersama-sama. Jika ada anak yang belum hafal kita ulang kita nasehati dan kita semangati terus. Anak-anak ya luar biasa akhlaknya, tapi alhamdulillah masih dalam tingkat kewajaran. Saya sendiri ngajar di TPA karena di Tpa al-ikhlas ini gurunya hanya 2, kalau stu jam 1 siang yang satunya jam 3 sore yang ngajar bu syika biasanya, muridnya sih lumayan sekitar 25 anak kalau yang saya ajar, kesulitannya mengendailakn anak jika ada yang berkelahi,lebih dari itu alhamdulillah aman. Saya sendiri disini lebih mengutamakan nasehat, dan nasehat, dan pembiasaan yang baik kepada anak murid saya." 28

Kemudian hal senada dengan pak Asel dan Ibu Ayu juga diungkapkaan oleh Ibu Eka selaku guru TPA Al-Islami di desa Lubuk Lingkuk beliau mengungkapkan bahwasannya beliau menggunakan metode nasehat, reward, cerita, dan pembiasaan

\footnotetext{
27 Asel, guru TPA Nurul Qomar. Wawancara. dusun B1, 26 September 2020

${ }^{28}$ Ayu, guru TPA Al-Iklas. Wawancara. Dusun Melingai, 27 September 2020
} 
"Mengkondisikan anak-anak ketika mengaji, karena kan ketika yang lain setoran maju kedepan biasanya anak-anak yang lain saya suruh menulis nah terkadang pada saat itu ada anak-anak yang jahil ganguin temennya, dan akhirnya ribut semua. Padahal asalnya satu orang nih sumbernya. Dan anakanak disini itu kalau di bilangin satu kali dek nurut, nak diulang due sampai tige kali baru die nurut. Ya dinasehati kalau misalnya sekedar nakal, ribut gak nurut. Karena disini tpa nya dikhususkan mengaji dan menulis tujuan utamanya jadi kalaupun ada pr misalnya pelajaran tambahan seperti bahasa Arab kalaupun anak tidak mengerjakan ya gak apa-apa tidak kena sanksi baik dari saya maupun dari guru yang lain. Jika sudah dinasehati 2 sampai 3 kali terus masih ndak nurut biasanya saya diemkan anak e, tapi malah diem die tu. Ada hadiah, dan hadiah nya seperti alat-alat tulis. Karena itukan yang bermanfaat buat mereka dan itupun kita berikan hadiah pada saat kegiatan lomba di TPA ini, misalnya pada saat acara 17 agustus, 1 muharram. Anakanak belajarnya 2 jam. Kegiatannya dimulai ketika anak sudah dateng berdoa setelah berdoa baca surat pendek bersama-sama, kemudian ada ceramah singkat 5 menit, atau cerita-cerita islami baru kemudian mengaji dan setoran hafalan30 menit sebelum pulang biasanya kami ulang kosakata bahasa Arab sebelumnya, dan tambahan kosakata baru kemudian tanya jawab dengan anak-anak. Pengaruhnya anak-anak tambah senang mengaji. Kalau perubahan terhadap akhlak iya ada, ada perubahan yang saya lihat pada anak-anak misalnya semakin tertib, karena itu kita terapkan sehari-sehari misal e kata-kata jangan marah maka bagimu syurga. Nah itu kena banget ke anak-anak. Kalau udah ada yang marah satu misal e ketika disebutkan kata-kata tersebut gak jadi marah dia, tapi kadangan malah ada yang nangis gitu kan. Iya kembali lagi namanya anak-anak. Kalau masalah hafalan saya tidak pernah menyuruh meghafalkan kosakata bahasa Arab karena dengan kita ulang sehari-hari dan bersama-sama tanpa saya suruh hafalan pun alhamdulillah anak-anak ketika ditanya bisa jawab itu. Kalau hafalan 
misalnya ada yang gak hafal bisanya saya suruh ngulang aja, kalau kali maju kedepan masih tidak hafal yang besoknya harus ngulang lagi surah yang dia baca sampai bener-bener hafal." 29

Dari pemaparan guru PAI dan guru TPA di Kecamatan Lubuk Besar khususnya dalam membentuk kepribadian akhlakul karimah anak, disinilah akan terlihat rasa kasih sayang seoraang guru dalam mendidik anak-anak dengan keihklasan dan kelembutan bukan dengan kekerasan. Menumbuhkan sifa jujur, berlaku baik sesama manusia, malu ketika melakukan dosa, bersikap sopan dan santun terhadap sesama manusia, mengajarkan sabar, birrul walidain, memiliki sifat pemaaf, dan selalu bersyukur kepada Allah atas nikmat yang selalu diberikan kepada kita maka disini para guru banyak menggunakan metode hukuman, pembiasaan, keteladanan karena dengan metode tersebut anak-anak lebih menurut, anak-anak selalu melihat sikap perilaku yang selalu dilakukan oleh guru akan selalu diikuti oleh anak-anak. Misalnya seperti tilawah Al-quran terlebih dahulu, mengambil wudhu terlebih dahulu, tidak membuang sampah sembarangan. ${ }^{30}$ dan dan cerita selain itu ada juga yang menggunakan metode cerita, nasehat dan pemberian hadiah atau reward.

Adapun cerita yang disampaikan berupa materi mengenai jujur, amanah, menjauhi sifat iri, tidak boleh sombong, kemudian dengan metode nasehat bapak dan Ibu guru selalu mengutamakan nasehat dalam mendidik anak-anak, karena menurut ke enam guru ini nasehat dan contoh yang baik akan selalu membekas dihati anak dibandingkan hukuman fisik, kekerasan, ataupun teriakan yang justru akan melukai hati setiap anak. Kemudian dalam hal pemberian hadiah ke enam guru sepakat bahwa hadiah yang diberikan tidak selalu berupa sesuatu yang besar, ada juga hadia yang sederhana namun akan berkesan di hati anak-anak karena mereka merasa dihargai

${ }^{29}$ Eka, Guru TPA Al-Islami Lubuk Lingkuk, Wawancara, Desa Lubuk Lingkuk, 28 September

30 Observasi kepada ke enam guru PAI dan TPA DI Kecamatan Lubuk Besar, 23-28 September 2020 
seperti pujian, acungan jempol, kata-kata hebat, pinter, walaupun terkadang berupa makan misalnya permen. Sebagaimana hasil wawancara diatas bersama ke enam guru yakni 3 orang guru PAI dan 3 orang guru TPA, mereka semua mengungkapkan bahwa sangat besar harapan para orangtua terhadap bapak dan ibu guru, karena para orangtua berharap anak-anak bisa membaca Al-quran dengan baik dan benar, dan juga akhlak anak-anak mereka diharapkan bisa berubah dengan ketika dibiasakan berada dilingkungan Agama. Karena para orangtua khususnya para pelaku nikah dini merasa belum mampu mendidik anak mereka ketika dirumah yang selalu tidak menurut kepada orangtua mereka.

\section{Daftar Pustaka}

Abdullah, M. Yatimin, Studi akhlak dalam perspektif Alquran, jakarta: Amzah, 2007.

Adisusilo, Sutarjo, 'Pembelajaran nilai karakter: Konstruktivisme dan VCT sebagai inovasi pendekatan pembelajaran afektif', Jakarta: Raja Grafindo Persada, 2012.

Afifuddin, Beni Ahmad Saebani, Metodologi Penelitian Kualitatif, Bandung : Pustaka Setia, 2012.

Afry Ramadhany, Menjadi Ibu yang Menyenangkan, Jakarta : Bhuana Ilmu Populer, 2015.

Alifah, Afunur, Pendidikan Akhlakul Karimah Di Pondok Pesantren Darul Abror Watumas Purwanegara Purwokerto Utara, Iain, 2017.

Amin, Suci and Rini Harianti, Pola Asuh Orangtua dalam Motivasi Belajar Anak, Yogyakarta : Budi Utama, 2018.

Arifin, Hubungan Timbal Balik Pendidikan Agama Islam di Lingkungan Sekolah dan Keluarga, Jakarta: Bulan Bintang, 1975.

Batubara, Jose R.L., 'Adolescent development (perkembangan remaja)', Sari pediatri, vol. 12, no. 1, 2016, pp. 21-9. 